\title{
CONTENT ANALYSIS OF MASTER'S DEGREE AND DOCTORATE THESES WHERE SOCIAL SKILLS TRAINING IS APPROACHED
}

\begin{tabular}{|c|c|}
\hline $\begin{array}{l}\text { Dr. Murat Teze } \\
\text { M.Sc. Şebnem Güld } \\
\text { Dr. Behçet Özna } \\
\text { Dr. Şeniz Şenso } \\
\text { M.Sc. Çilem Çaltıl }\end{array}$ & $\begin{array}{l}\text { East University, Atatürk Education Faculty, North Cyprus } \\
\text { E-mail: murat.tezer@neu.edu.tr } \\
\text {, Near East University, Atatürk Education Faculty, North Cyprus } \\
\text { E-mail: sebnem.guldal@neu.edu.tr } \\
\text { ear East University, Atatürk Education Faculty, North Cyprus } \\
\text { E-mail: behcet.oznacar@neu.edu.tr } \\
\text { rr East University, Atatürk Education Faculty, North Cyprus } \\
\text { E-mail: seniz.sensoy@neu.edu.tr } \\
\text { Near East University, Atatürk Education Faculty, North Cyprus } \\
\text { E-mail: cilem.caltikusu@neu.edu.tr }\end{array}$ \\
\hline A R T I C L E I N F O & $\begin{array}{l}\text { A B S T R A C T } \\
\text { Social skills play an important role in interpersonal social skills. This }\end{array}$ \\
\hline $\begin{array}{l}\text { Original Research } \\
\text { Received: December, } 29.2018 . \\
\text { Revised: January, 27.2019. } \\
\text { Accepted: February, } 16.2019 . \\
\text { doi:10.5937/ijcrsee1901043T }\end{array}$ & $\begin{array}{l}\text { study investigates social skills training concept in general sense in articles, } \\
\text { master and doctorate degree programs. Literature review was made in the } \\
\text { research between the years } 2010-2017 \text {. In this literature review process the } \\
\text { concepts of publication type, subject area, publication year, research design, } \\
\text { data collection tool, sample group, province and department concepts were } \\
\text { discussed for social skills training. Study group meta-analysis technique }\end{array}$ \\
\hline $\begin{array}{l}\text { UDK } \\
316.62-057.875 \\
378(560)\end{array}$ & $\begin{array}{l}\text { was used in this research. Thirty-eight articles and the theses existing in } \\
22 \text { master's degree and } 21 \text { doctorate program in Turkish Council of Higher } \\
\text { Education National Thesis Centre and Google Scholar were analysed. }\end{array}$ \\
\hline
\end{tabular}

Keywords:

(C) 2019 IJCRSEE. All rights reserved.

higher education,

graduate education,

social skills training,

content analysis.

\section{INTRODUCTION}

History of education is based on the beginning of human history. However, education directed a number of developments and changes within the time passed from the beginning of human history to the present day. Modern education within this process aims at the development of physical, emotional and social skills most appropriately for individuals and their society (Price, 2018). This situation caused an important development and change in higher education systems. Therefore, it be-

Corresponding Author

Dr. Murat Tezer, Near East University, Atatürk

Education Faculty, North Cyprus

E-mail: murat.tezer@neu.edu.tr

\section{cc) (i) $\Theta$}

This work is licensed under a Creative Commons Attribution - NonCommercial - NoDerivs 4.0. The article is published with Open Access at www.ijcrsee.com came necessary for higher education to have international demand, structure, and standards in globalization.

In recent years, training programs within the framework of harmonization with the European Union at higher education level too as well as radical changes and developments have been prepared again with the transition from traditional education into modern education. Postgraduate education programs are prepared by the institutions at universities and confirmed by the Council of Higher Education. Any change that will be made in each teaching phase of education will influence level programs also in other education levels at the same time (Creasy, 2018).

Human being is a social entity. Human being enters in interaction process by establishing social relationships with the environment. Social skills of those individuals who can establish healthy relationships within this interaction process are developed (Kansky, and Allen, 2018). It can be said that the most 
important factor in developing and sustaining the presence of human is the adaptation. Human being comes to the world as biological asset, adapts the environment and sustains his/her life (Samanc1 and Diş, 2014). Consequently, social development is an acquired behaviour complying social expectations as well as cognitive, affective and physical development considering the characteristics of individuals existing in development process (Ihmeideh, 2019). Development of social skills in the literature is a concept identical as social competence. Social competence is about the adaptation within the social structure. Social skills imply an individual to behave accordingly with the acts expected by the society (Ng, 2018).

Social skills started to develop after 1970s in childhood. The investigations about this field were supported with the object of the description of the children's social skills and evaluation of children's social skills deficiency, display of approaches suitable interference.

It is possible to reach the related definitions about social skills in the related literature review. Walker (1995) described social skills as specific strategies that were used in order to carry out the social duty that were given to common expectation. Social skills intended to maintain the communication and interaction, can be repeated, can be determined. As another definition of social skills, initiation and continuation of positive interactions by individuals with others are important acts (Bourne, Andersen-Warren and Hackett, 2018). Consequently, like several conceptions, as well social skills conception was attempted to be explained with different descriptions by different people. When the descriptions of social skills are examined, it is a generally accepted statement in all definitions that a person may respond appropriately giving the meaning of the counter party's behaviours in individual's relationships (Tomlinson, 2018). With this statement, social skills have an effective role of facilitate the communication of individual with other people (Jam et all, 2018).

Some children in social skills may encounter with several problems in their professional life and interpersonal relationships and emotional-behavioural matters throughout their life academically. According to Uz-Baș (2003), in the consequence of his work on the students that attending $4^{\text {th }}$ and $5^{\text {th }}$ primary school it is claimed that there is a positive and significant relationship between the children's social skills and the school compatibility; there is a negative and significant relationship between the academic success and depression level. With this result, it is claimed that the social skills of the children that will gained at childhood period, the negative psychological emotions of children are effective on their academic success. Because of a conducted work, Chen (2018) determined that incompatible children in proportion to usual children have low-level problem solving and social skills. In order to eliminate these problems it is required to ensure integration of the children with the society increasing their social skill levels. The results of the work about the subject show that social skill trainings of the children are effective on their social skills acquisition (Paulus and Leitherer, 2017).

It is important to develop effective and efficient programs and appropriate learning methods in social skills training. Teaching of the game applied in early child-hood period is reflected into the development of social skills of children is emphasized in the study conducted by Pavão et all, (2019).

Supporting social skills in early years of life influences the development of behaviour that an individual will exhibit (Miller et all, 2017).

Veziroglu-Celik and Acar (2018) stated that early years of life are very critical in terms of designing cognitive, personal and social behaviours. If the children fall behind the social development living in crises from their birth to 12 years, solving problems, acquiring social skills like dealing with problems, developing self-reliance and self-discipline are getting harder for the children. The early childhood is an appropriate period for children to learn social skills in terms of social adaptation in future personal development. This period also supported social skills that children developed over problematic behaviours (Ahn, Byun and Kwon, 2017).

Human being is a social entity in nature. Individuals cannot sustain their life by only meeting their physical needs out of their overall needs. They sustain their life for meeting their needs such as safety, respect, love, etc. that are provided in upper steps of Maslow's pyramid. People feel the need of sharing their emotions, thoughts and expectations throughout their life. In order that this could be realized effectively, it is directly related to the power of individuals' social skills (Samanc1 and Diş, 2014).

In this research the studies about social skills training are analysed in terms of publi- 
cation type, subject area, publication year, research design, data collection tool, sample group, province and department. These studies are tried to be revealed in regard of which subjects they are concentrated around. In this direction, the study makes a significant contribution to the literature revealing how the studies follow the social skills training within a period of eight years approximately.

\section{MATERIALS AND METHODS}

The research model, data collection and data analyses of the current study are dealt in parallel with the objectives. In this study qualitative data analysis method is used which is thought appropriate to our objectives. Because the content analysis is to bring together the data similar to each other under certain conceptions and themes, and to organize and interpret them in such a way that a reader could understand them (Yıldırım and Şimşek, 2013). The content analysis is a systematic, replicable technique that can be summarized with smaller content categories of a text, which is based on certain guidelines.

The theses analysed in this research are restricted with the dissertations that are accessible in PDF extension as of $13^{\text {th }}$ November 2017. from the National Thesis Centre of the Council of Higher Education. This working group consists of 22 Master's Thesis, 21 Doctoral Thesis and 38 articles. In addition, the thesis that are written only in Turkish are included in the research in respect of 13. November 2017. with reference to "Social Skills Training" code concept. Totally 43 thesis are reached with the scanning belonging to 20102017 conducted in Turkish Council of Higher Education National Thesis Centre (YOKTEZ) Head Office. The articles analysed in research include 38 studies. Following parameters are used in restricting research articles:

1. Google academic data is used in order to determine research articles.

2 . The articles, which are published only between 2010-2017. years, are analysed in the research.

3 . The articles, which are written only in Turkish and published in national peer-reviewed journals, are analysed.

Totally nine questions were included in analysing totally 81 studies regarding Social Skills Training (SST) that were included in the sample of this research. Each of the questions is evaluated as a "theme" for the content analysis instruction used in the research. The questions located in content analysis instruction are given below.

1. What is the distribution of studies related to SST in respect of publication type?

2 . What is the distribution of studies related to SST in respect of the subject area?

3 . What is the distribution of studies related to SST in respect of publishing date?

4. What is the distribution of studies related to SST in respect of the research design?

5 . What is the distribution of studies related to SST in respect of the data collection tool?

6. What is the distribution of studies related to SST in respect of the data solution?

7. What is the distribution of studies related to SST in respect of sample group type?

8 . What is the distribution of studies related to SST in respect of the provinces?

9. What is the distribution of studies related to SST in respect of the department?

In this study totally 81 studies which were subjected to the content analysis were read several times, themes were formed for 11 questions in the guidelines of content analysis and encoded one by one. The data were encoded twice independently at two different times by the researcher in order to provide the indoor consistency (reliability) in coding. The second coding was conducted after two weeks upon the first coding. Later the two codes were compared with each other and calculated by applying the formula (Reliability $=$ Consensus / Consensus + Divergence X 100) of Miles \& Huberman (1994). The conformity between the two coding was calculated as $100 \%$ in the reliability study that was put into practice specific for this research.

\section{RESULTS}

In this department the data obtained related to the themes questioned with nine questions in content analysis instruction are presented into tables.

Table 1. The Distribution of Studies Related to SST in Respect of Publication Type

\begin{tabular}{lcc}
$\begin{array}{c}\text { Publication } \\
\text { Type }\end{array}$ & F & \% \\
\hline Master's Thesis & 22 & 27 \\
\hline Doctoral Thesis & 21 & 26 \\
\hline Research Article & 38 & 47 \\
\hline
\end{tabular}

Table 1 shows the distribution of studies 
related to SST in respect of publication type. As indicated in Table 1, $22(27 \%)$ of the total 81 studies were conducted in the master's degree level, $21(26 \%)$ of them were doctorate level and $38(47 \%)$ of them were in the scope of research article. This standing shows that there is a requirement to multiple researches at doctorate level with regard to SST.

Table 2 shows the distribution of studies related to SST in respect of subject area. According to Table 2, totally 21 different topic studies have occurred related to SST. The subject areas in which the most studies are done are respectively: (i) SST in primary education social skills (30\%), (ii) SST in preschool social skills (21\%) and (iii) SST in the family (11\%). The subject areas in which the least studies are done are: (i) Social skills in secondary education, Social Skills in Medium education students, Social skills in harmonized class, Social skills in life sciences, Social skills in social science lesson, Social skills in the school, Social Skills in universities, Social skills of school psychological counsellors in problem solving, Social skills in broken families, activity-based Social Skills, Social skills in Latin dances, Social skills in social concern, Social skills in hidden curriculum, Social skills in primary school management (1\%) Among the 81 studies examined, finding only one study in these subject areas shows that there is a need to work more in these areas.

Table 2. The distribution of studies related to SST in respect of the subject area

\begin{tabular}{lcc}
\hline \multicolumn{1}{c}{ Subject Area } & F & $\%$ \\
\hline SST in pre-school education & 15 & 21 \\
SST in primary education & 21 & 30 \\
SST in secondary education & 1 & 1 \\
SST in the family & 8 & 11 \\
SST in autism spectrum & 4 & 6 \\
disorder & & \\
SST in gifted students & 3 & 4 \\
SST in people with mental & 2 & 3 \\
disabilities & & \\
SST in harmonized class & 1 & 1 \\
SST in life sciences & 1 & 1 \\
SST in social science lesson & 1 & 1 \\
SST in the school & 1 & 1 \\
SST in universities & 1 & 1 \\
SST of school psychologi- & & \\
cal counsellors in problem & 1 & 1 \\
solving & & \\
SST in broken families & 1 & 1 \\
Activity based SST & 1 & 1 \\
SST in Latin dances & 1 & 1 \\
SST in social concern & 1 & 1 \\
SST in hidden curriculum & 1 & 1 \\
SST in primary school & 1 & 1 \\
management & 4 & 6 \\
SST in nursery class & & \\
\hline
\end{tabular}

Table 3 shows the distribution of studies related to SST in respect of publishing year. According to Table 3, study findings about totally eight publishing year is delivered related to SST. The years of publication in which most of the work is done are respectively as follows: The highest three distribution of publishing date of SST are $23 \%$ in $2015,16 \%$ in 2010 and $15 \%$ in 2013. Distribution of the least publishing year is 6\% in 2017 .

Table 3. Distribution of studies related to SST in respect of the publishing year

\begin{tabular}{ccc}
\hline Publishing Year & F & \% \\
\hline 2010 & 13 & 16 \\
\hline 2011 & 8 & 10 \\
\hline 2012 & 7 & 9 \\
\hline 2013 & 12 & 15 \\
\hline 2014 & 9 & 11 \\
\hline 2015 & 19 & 23 \\
\hline 2016 & 8 & 10 \\
\hline 2017 & 5 & 6 \\
\hline
\end{tabular}

Table 4. Distribution of studies related to SST in respect of the research design

\begin{tabular}{lcc}
\hline \multicolumn{1}{c}{ Research Design } & F & \% \\
\hline Relational Survey Model & 9 & 11 \\
\hline Survey Model & 15 & 19 \\
\hline Quantitative & 21 & 26 \\
\hline Qualitative & 10 & 12 \\
\hline Mixed & 11 & 14 \\
\hline Descriptive & 3 & 4 \\
\hline Experimental & 21 & 26 \\
\hline
\end{tabular}

Table 4 indicates the distribution of studies related to SST in respect of the research design. According to Table 4, 7 research design findings that were used in the studies regarding SST were obtained. The most frequently used research designs are respectively as follows: Experimental (26\%), Quantitative (26\%), Survey $(19 \%)$. The least used research design was descriptive one $(4 \%)$. 
Table 5. Shows the distribution of the studies related to SST in respect of data collection tool.

\begin{tabular}{|c|c|c|}
\hline Data Collection & $\mathbf{F}$ & $\%$ \\
\hline Nominative Well-Being Scale & 1 & 1 \\
\hline Social Skills Scale & 18 & 23 \\
\hline Interview Form & 5 & 7 \\
\hline Social Skills Evaluation Scale & 17 & 21 \\
\hline Self-Conception for Children & 1 & 1 \\
\hline Social Skills Inventory & 5 & 7 \\
\hline Personal Information Form & 14 & 18 \\
\hline Ankara Development Inventory & 1 & 1 \\
\hline Pre-school Social Behaviour Scale & 5 & 7 \\
\hline $\begin{array}{l}\text { Child and Parents Relationship } \\
\text { Scale }\end{array}$ & 1 & 1 \\
\hline Self-Control Ability & 1 & 1 \\
\hline General Self-Efficacy Scale & 1 & 1 \\
\hline Social Physics Anxiety Inventory & 1 & 1 \\
\hline $\begin{array}{l}\text { Being Satisfied with Physical } \\
\text { Points }\end{array}$ & 1 & 1 \\
\hline Main Characteristics Scale & 1 & 1 \\
\hline Gilliam's Autistic Disorder Scale & 1 & 1 \\
\hline Academic Success Test & 1 & 1 \\
\hline Social Focus Grouping Scale & 1 & 1 \\
\hline Social Values Scale & 1 & 1 \\
\hline Assessment of Mother Curriculum & 1 & 1 \\
\hline Social Acceptance Scale & 1 & 1 \\
\hline $\begin{array}{l}\text { Walker-McConnell Social } \\
\text { Competence and Adaptation to } \\
\text { School Scale }\end{array}$ & 1 & 1 \\
\hline Rosenberg Self Esteem Scale & 1 & 1 \\
\hline
\end{tabular}

According to Table 5, totally 23 data collection tools were used in the studies regarding SST. The most frequently used research designs are respectively as follows: Social Skills Evaluation Scale is $23 \%$ social skills evaluation scale is $21 \%$ and personal information form is $18 \%$. Child and Parents Relationship Scale, Self-Control Ability, General Self-Efficacy Scale, Social Physics Anxiety Inventory, Being Satisfied with Physical Points, Main Characteristics Scale, Gilliam's Autistic Disorder Scale, Academic Success Test, Social Focus Grouping Scale, Social Values Scale, Assessment of Mother Curriculum, Social Acceptance Scale, Walker McConnell's
Social Competence and Adaptation to School Scale, Rosenberg Self Esteem Scale were used as the least data collection tools (1\%).

Table 6. Sample groups distribution of the study regarding SST

\begin{tabular}{lcc}
\hline Sample Groups & F & $\%$ \\
\hline Mothers & 3 & 4 \\
\hline High school students & 1 & 1 \\
\hline Pre-school teacher & 2 & 2 \\
\hline $\begin{array}{l}\text { Classroom teacher lec- } \\
\text { turing at primary school }\end{array}$ & 1 & 1 \\
\hline Adolescents & 1 & 1 \\
\hline Students not dancing & 4 & 5 \\
\hline Primary school students & 24 & 30 \\
\hline $\begin{array}{l}\text { Primary school admin- } \\
\text { istrators }\end{array}$ & 1 & 1 \\
\hline $\begin{array}{l}\text { Students with mental } \\
\text { deficiency }\end{array}$ & 1 & 1 \\
\hline Special training teachers & 1 & 1 \\
\hline Teacher candidate & 2 & 3 \\
\hline Pre-school students & 40 & 50 \\
\hline
\end{tabular}

Table 6 shows the sample group distribution of the studies related to SST in twelve types. While the pre-school $(50 \%)$ program was mostly used in the sampling of SST, the sampling of the studies regarding SST the least one $(1 \%)$ was used in in content analysis with primary school administrators, students with mental disorders, teachers of special training.

Table 7. Distribution of the study according to provinces of Turkey regarding SST

\begin{tabular}{lcc}
\hline Provinces & F & $\%$ \\
\hline Ankara & 16 & 19 \\
\hline Mersin & 2 & 3 \\
\hline Istanbul & 18 & 22 \\
\hline İzmir & 12 & 14 \\
\hline Gümüşhane & 1 & 1 \\
\hline Konya & 4 & 5 \\
\hline Afyon & 5 & 6 \\
\hline Manisa & 1 & 1 \\
\hline Elağız & 1 & 1 \\
\hline Bolu & 1 & 1 \\
\hline Malatya & 1 & 1 \\
\hline Erzurum & 1 & 1 \\
\hline Tokat & 1 & 1 \\
\hline Edirne & 1 & 1 \\
\hline Kayseri & 2 & 3 \\
\hline Uşak & 2 & 3 \\
\hline Adana & 3 & 4 \\
\hline Sivas & 2 & 3 \\
\hline Çankırı & 2 & 3 \\
\hline KahramanMaraş & 2 & 3 \\
\hline Muş & 2 & 3 \\
\hline Denali & 1 & 1 \\
\hline & & \\
\hline
\end{tabular}


Table 7 indicates the distribution of the studies regarding SST in twenty-four different provinces. The most widely used distribution is Istanbul $(22 \%)$ in SST, whereas the least used ones are Mersin, Gümüşhane, Konya, Manisa, Elağız, Bolu, Malatya, Erzurum, Tokat, Edirne and Denizli (1\%) regarding SST.

Table 8. Departmental distribution of the study regarding SST

\begin{tabular}{lcc}
\hline Department & F & \% \\
\hline Educational sciences & 5 & 6 \\
\hline Primary education & 21 & 26 \\
\hline Institute of social sciences & 5 & 6 \\
\hline Psychology & 7 & 9 \\
\hline $\begin{array}{l}\text { Child development and } \\
\text { home management }\end{array}$ & 5 & 6 \\
\hline $\begin{array}{l}\text { Physical education and } \\
\text { sports teaching }\end{array}$ & 4 & 5 \\
\hline Recreation & 4 & 5 \\
\hline $\begin{array}{l}\text { Education programs and } \\
\text { teaching }\end{array}$ & 3 & 4 \\
\hline Teaching for the blind & 2 & 2 \\
\hline Special training & 7 & 9 \\
\hline Fine arts & 2 & 2 \\
\hline $\begin{array}{l}\text { Psychological Counselling } \\
\text { and Guidance }\end{array}$ & 4 & 5 \\
\hline $\begin{array}{l}\text { Child development and } \\
\text { education }\end{array}$ & 12 & 15 \\
\hline
\end{tabular}

Table 8 shows the departmental distribution of the studies related to SST in thirteen types. While the highest distribution among departments with regard to SST is in primary education with $26 \%$, the least one is in teaching for blind and fine arts with $2 \%$.

\section{DISCUSSIONS}

The content analysis, which was made with regard to social skills training, was investigated under the scope of master's thesis, doctoral thesis and articles according to publication type. Kahveci and Ataman (2017) conducted a study on the effect of consolidated behavioural consultation program on communication/social skills and inappropriate behaviours of blind autistic child. No actual resources have been encountered in recent years regarding social skills training. This can underline the importance in needing master's theses and doctoral these studies with regard to social skills training.

It can be concluded from the research that the studies about social skills training in pre-school and primary school are cared more. In fact, it is possible to make research on special training and different educational levels regarding social skills training.

As a result of the content analysis made in relation to social skills training, it was concluded that social skills training was utilized between 2010. and 2017. predominantly in the database of YOKTEZ and google scholar. The social skills training can be enriched within 10 years through related actual resources.

Most of the studies used the experimental research design with regard to social skills training. It was concluded that the there were less studies in which both quantitative and qualitative ones were conducted together. Karateke and Ömeroğlu (2017) separated into two the examination of the effect of social skills training program that is applied to children having a potential of superior ability on the development of social skills. Validity and reliability studies were conducted for the Coloured Progressive Matrices test in the first chapter of the research, and the analysis of education program was made in the second chapter. Single grouped pre-test and post-test experimental design without control group were used in the study out of test models in the second chapter. However, it can be said that pre-test and post-test design was used frequently in experimental studies.

The social skills mostly used as data collection tool in the related researches regarding the relevant literature was rating scale. SPSS and content analysis were used in the research in analysing data. In the distribution of sampling related to social skills training, we can see most frequently pre-school and primary school students.

In the distribution of the study according to provinces regarding SST there are Istanbul and Ankara. In fact, we can say that most of the study regarding SST is distributed in the department of primary school.

\section{CONCLUSIONS}

As a conclusion, it was found that social skills training was utilized for the last seven years until 2017. predominantly. Most of the studies used the experimental research design with regard to social skills training. It was concluded that the there were less studies in which both quantitative and qualitative ones were conducted together. Content analysis were used in the research in analysing data. 
Tezer, M., et all. (2019). Content analysis of master's degree and doctorate theses where social skills training is approached, International Journal of Cognitive Research in Science, Engineering and Education (IJCRSEE), 7(1), 43-49

In the distribution of sampling related to social skills training, we can see most frequently preschool and primary school students.

\section{ACKNOWLEDGEMENTS}

We would like to express our gratitude to our institute, Near East University, that has provided many experiences in term of research.

\section{Conflict of interests}

The authors declare no conflict of interest.

\section{REFERENCES}

Ahn, J., Byun, M. H., \& Kwon, J. S. (2017). Trajectory of problem behaviours of Korean adopted children: using piecewise hierarchical linear growth modelling. Child \& Family Social Work, 22(1), 461-471. https://doi.org/10.1111/cfs.12264

Bourne, J., Andersen-Warren, M., \& Hackett, S. (2018). A systematic review to investigate dramatherapy group work with working age adults who have a mental health problem. The Arts in Psychotherapy, 61, 1-9. https://doi.org/10.1016/j. aip.2018.08.001

Büyüköztürk, Ş., Çakmak, E. K., Akgün, Ö. E., Karadeniz, Ş., \& Demirel, F. (2017). Bilimsel araştırma yöntemleri. Pegem Atıf Indeksi, 1-360. https:// doi.org/10.14527/9789944919289

Chen, J. (2018). Efficacious and Positive Teachers Achieve More: Examining the Relationship Between Teacher Efficacy, Emotions, and Their Practicum Performance. The Asia-Pacific Education Researcher, 1-11. https://doi.org/10.1007/ s40299-018-0427-9

Creasy, R. (2018). Seeing Education as a Process. In The Taming of Education (pp. 1-9). Palgrave Macmillan, Cham. https://doi.org/10.1007/ s11092-008-9064-9

Ihmeideh, F. (2019). Getting parents involved in children's play: Qatari parents' perceptions of and engagement with their children's play. Education 3-13, 47(1), 47-63. https://doi.org/10.1080 /03004279.2017.1399152

Jam, A. Z., Talab, R. H., Sheikh, M., Torabi, F., \& Rafie, F. (2018). The effect of 16 weeks gymnastic training on social skills and neuro-psychiatric functions of autistic children. Sport Sciences for Health, 14(1), 209-214. https://doi.org/10.1007/ s11332-018-0436-3

Kahveci, G., \& Ataman, A. (2017). The Effect of Conjoint Behavioral Consultation Program Related Teaching on Problem Behavior and Communication/Social Skills with a Blind and Autistic Child. Journal of Education and Learning, 6(4), 372. http://files.eric.ed.gov/fulltext/EJ1161295. pdf

Kansky, J., \& Allen, J. P. (2018). Long-term risks and possible benefits associated with late adolescent romantic relationship quality. Journal of youth and adolescence, 1-14. https://doi.org/10.1007/ s10964-018-0813-x
Karateke, B., \& Ömeroğlu, E. (2017). Giftedness in Early Childhood. Current Trends in Educational Sciences, 83. http://www.academia.edu/ download/55309994/Current_Trends_in_Education Sciences.pdf\#page $=83$

Miller, C. F., Kochel, K. P., Wheeler, L. A., Updegraff, K. A., Fabes, R. A., Martin, C. L., \& Hanish, L. D. (2017). The efficacy of a relationship building intervention in $5^{\text {th }}$ grade. Journal of school psychology, 61, 75-88. https://doi.org/10.1016/j. jsp.2017.01.002

Ng, C. H. C. (2018). High School Students' Motivation to Learn Mathematics: The Role of Multiple Goals. International Journal of Science and Mathematics Education, 16(2), 357-375. https:// doi.org/10.1007/s10763-016-9780-4

Paulus, M., \& Leitherer, M. (2017). Preschoolers' social experiences and empathy-based responding relate to their fair resource allocation. Journal of experimental child psychology, 161, 202-210. https://doi.org/10.1016/j.jecp.2017.03.005

Pavão, I., Santos, F., Wright, P. M., \& Gonçalves, F. (2019). Implementing the teaching personal and social responsibility model within pre-school education: strengths, challenges and strategies. Curriculum Studies in Health and Physical Education, 10(1), 51-70. https://doi.org/10.1080/25 742981.2018 .1552499

Price, A. (2018). Using outdoor learning to augment social and emotional learning (SEL) skills in young people with social, emotional and behavioural difficulties (SEBD). Journal of Adventure Education and Outdoor Learning, 1-14. https:// doi.org/10.1080/14729679.2018.1548362

Samanc1, O., \& Diş, O. (2014). Sosyal becerileri zayıf olan ilkokul ögrrencilerinin tutum ve davranışlarının öğretmen görüşlerine göre değerlendirilmesi. Kastamonu eğitim dergisi, 22(2), 573-590. http://dergipark.gov.tr/download/article-file/209937

Tomlinson, M. (2018). Competences, capabilities and capitals: conceptual paradigms in the education-employment relationship. In Essays on Employer Engagement in Education (pp. 71-85). Routledge. https://www. taylorfrancis.com/books/e/9781351386678/ chapters/10.4324/9781315144115-12

Uz Baş, A. (2003). İlköğretim 4. ve 5. sınıflarda okuyan öğrencilerin sosyal becerileri ve okul uyumu ile depresyon düzeyleri arasındaki ilişskinin incelenmesi (Doctoral dissertation, DEÜ Eğitim Bilimleri Enstitüsü). http://acikerisim.deu.edu. tr/xmlui/bitstream/han-dle/12345/7549/128158. pdf? sequence $=1 \&$ isAllowed $=\mathrm{y}$

Veziroglu-Celik, M., \& Acar, I. H. (2018). The association between learning behaviours and social competence of Turkish preschool children. Early Child Development and Care, 1-11. https:// doi.org/10.1080/03004430.2018.1542386

Walker, H. M. (1995). Walker-McConnell scale of social competence and school adjustment, Elementary version. San Diego, CA: Singular Publishing Group.

Yıldırım, A. \& Şimșek, H. (2013). Sosyal Bilimlerde Nitel Araştırma Yöntemleri. SeçkinYayıncılık. Ankara. 